\title{
Y-STR variation among Slavs: evidence for the Slavic homeland in the middle Dnieper basin
}

\author{
Krzysztof Rębała • Alexei I. Mikulich · Iosif S. Tsybovsky • \\ Daniela Siváková · Zuzana Džupinková · \\ Aneta Szczerkowska-Dobosz · Zofia Szczerkowska
}

Received: 15 September 2006/Accepted: 7 February 2007/Published online: 16 March 2007

(C) The Japan Society of Human Genetics and Springer 2007

\begin{abstract}
A set of 18 Y-chromosomal microsatellite loci was analysed in 568 males from Poland, Slovakia and three regions of Belarus. The results were compared to data available for 2,937 Y chromosome samples from 20 other Slavic populations. Lack of relationship between linguistic, geographic and historical relations between Slavic populations and Y-short tandem repeat (STR) haplotype distribution was observed. Two genetically distant groups of Slavic populations were revealed: one encompassing all Western-Slavic, Eastern-Slavic, and two Southern-Slavic populations, and one encompassing all remaining Southern
\end{abstract}

K. Rębała $(\bowtie) \cdot$ Z. Szczerkowska

Department of Forensic Medicine,

Medical University of Gdansk,

ul. Marii Skłodowskiej-Curie 3A,

80-210 Gdansk, Poland

e-mail: k.rebala@amg.gda.pl

\section{A. I. Mikulich}

Institute for the Study of Arts, Ethnography and Folklore,

National Academy of Sciences, Minsk, Belarus

I. S. Tsybovsky

Institute of Problems of Criminology,

Criminalistics and Forensic Expertise, Minsk, Belarus

D. Siváková

Department of Anthropology, Comenius University,

Bratislava, Slovakia

\section{Z. Džupinková}

Department of Experimental and Applied Genetics, Institute of Preventive and Clinical Medicine,

Slovak Medical University, Bratislava, Slovakia

A. Szczerkowska-Dobosz

Department of Dermatology,

Medical University, Gdansk, Poland
Slavs. An analysis of molecular variance (AMOVA) based on Y-chromosomal STRs showed that the variation observed between the two population groups was $4.3 \%$, and was higher than the level of genetic variance among populations within the groups (1.2\%). Homogeneity of northern Slavic paternal lineages in Europe was shown to stretch from the Alps to the upper Volga and involve ethnicities speaking completely different branches of Slavic languages. The central position of the population of Ukraine in the network of insignificant AMOVA comparisons, and the lack of traces of significant contribution of ancient tribes inhabiting present-day Poland to the gene pool of Eastern and Southern Slavs, support hypothesis placing the earliest known homeland of Slavs in the middle Dnieper basin.

Keywords Y chromosome - Microsatellites .

Slavic populations

\section{Introduction}

Since the human $\mathrm{Y}$ chromosome is characterised by the presence of the largest non-recombining region in the whole human genome, sensitivity of genetic variation to drift phenomena, a unique inheritance pattern and specificity to males, its polymorphism has been widely studied by researchers interested in human evolution and forensic geneticists (Jobling and Tyler-Smith 2003; Butler 2003). Depending on the time scales of the population history events, different types of polymorphic markers abundant on the Y chromosome are available for research. Analysis of slowly evolving Y-chromosomal biallelic polymorphisms have enabled deeper insight into prehistoric population movements and colonisation waves in Europe 
(Semino et al. 2000; Rootsi et al. 2004). On the other hand, Y-chromosomal short tandem repeats (Y-STRs) are characterised by a relatively high mutation rate and seem to be much more suitable for genetic studies of more-recent events. Although the combination between Y-chromosomal microsatellites and biallelic polymorphisms yields the highest level of resolution and a means of clarifying complex genetic histories (Weale et al. 2001, 2002; Das et al. 2004), Y-STR data alone also provide very useful information for analyses of interpopulation diversity and have been widely applied in resolving differentiation of various human populations (Kayser et al. 2001; Ploski et al. 2002; Caglià et al. 2003; Roewer et al. 2005; Immel et al. 2006).

The Indo-European linguistic family has the largest number of speakers of the recognised families of languages in the world today. In this family, Slavic languages form a group of closely related languages with close to 250 million speakers worldwide (Schenker 1995). In Europe, Slavs are the most numerous ethnic and linguistic group of peoples, residing chiefly in eastern and southeastern Europe but also extending across northern Asia to the Pacific Ocean. The early medieval great migrations in Europe utterly changed the ethnic and linguistic situation of the continent and spread the Slavic settlement in the fifth to sixth centuries over the major part of Eastern Europe, leading to the ethno-cultural subdivision of the primarily united Proto-Slavic community (Encyclopædia Britannica 2006). Nowadays, from the linguistic, cultural and geographic point of view, Slavs are customarily divided into three major subgroups: Eastern Slavs (Belarusians, Russians, Ukrainians), Western Slavs (Poles, Slovaks, Czechs, Lusatians), and Southern Slavs (Slovenes, Croats, Bosnians, Montenegrins, Serbs, Macedonians, Bulgarians).

Since the ethno-cultural subdivision of Slavs and the formation of modern Slavic nations took place quite recently, and significant differences in Y-STR haplotype distribution exist even between closely related human populations (Roewer et al. 1996), hypervariable Y-chromosomal microsatellites seem to be markers of choice for the study of mutual relations between different Slavic ethnic groups. So far, it was demonstrated that Slavic YSTR haplotype paternal lineages form a separate branch in a phylogenetic tree of European populations (Roewer et al. 2001, 2005). However, no comprehensive analysis of interpopulation Y-STR haplotype variation between different Slavic groups was available. This study has focused on providing a phylogenetic overview of closely related Central-Eastern European populations of Poland, Slovakia and Belarus to analyse their relationship with each other and with other Slavic populations, and to investigate how these relations reflect Slavs' historical migrations.

\section{Materials and methods}

Eighteen Y-chromosomal microsatellite loci: DYS19, DYS388， DYS389I， DYS389II， DYS390, DYS391, DYS392, DYS393, DYS426, DYS437, DYS438, DYS439, DYS460, GATA H4.1, DYS385 a/b, and YCAII a/b, were genotyped in randomly selected, unrelated Poles $(n=208)$, Slovaks $(n=164)$ and Belarusians $(n=196)$ by means of a multiplex polymerase chain reaction (PCR) and capillary electrophoresis, as previously described (Rębała and Szczerkowska 2005). The Belarusian population included samples from three distinct regions: 86 males from southern Belarus, 57 males from central Belarus, and 53 males from northern Belarus. Additionally, all Belarusian samples were genotyped at the M46 (Tat) locus by a PCR restriction fragment-length polymorphism (RFLP) method (Kayser et al. 2005). The products of amplification of the M46 locus were digested with Hsp92II restriction endonuclease (Rybakowski et al. 2002), separated by polyacrylamide gel electrophoresis, and visualised by silver staining. The Y-STR haplotype data for other 20 Slavic $(n=2,937)$ and nine neighbouring non-Slavic $(n=1,428)$ populations were obtained either from the Y chromosome haplotype reference database (http://www.ystr.org) (Roewer et al. 2001) or from the literature (Pepinski et al. 2004a, b; Lauc et al. 2005; Lovrečić et al. 2005; Marjanovic et al. 2005; Peričić et al. 2005; Spiroski et al. 2005; Lessig et al. 2006; Rodig et al. 2007).

Analysis of molecular variance (AMOVA) was performed with the use of Arlequin 3.1 software (Excoffier et al. 2005) to calculate matrices of pairwise $F_{\mathrm{ST}}$ and $R_{\mathrm{ST}}$ values between populations. Associated probability values were estimated from 10,100 permutations. Linearised $F_{\mathrm{ST}}$ and $R_{\mathrm{ST}}$ values (Slatkin 1995) were applied to build a neighbour-joining tree using the options NEIGHBOUR and DRAWTREE in the PHYLIP package (Felsenstein 2004), and to conduct a multidimensional scaling analysis using the STATISTICA 7.1 software (StatSoft). In all calculations, DYS389 was considered as a haplotype of two independent loci: DYS389I (repetitive stretches: $p+q$ ) and DYS389II-I (repetitive stretches: $m+n$ ) (Rolf et al. 1998), while microvariants, null alleles and locus multiplications were treated as missing data.

\section{Results and discussion}

AMOVA of 18-locus Y chromosome haplotypes revealed significant differences between the populations of Belarus, Poland and Slovakia $\left(F_{\mathrm{ST}}=0.0100 ; P<0.0001\right)$ as well as between the three Belarusian subpopulations $\left(F_{\mathrm{ST}}=\right.$ 0.0084; $P=0.0034)$. Analysis of pairwise $F_{\mathrm{ST}}$ values for 18 Y-STRs demonstrated that heterogeneity within the 
Belarusian population was caused by differences between northern and central Belarus while the remaining pairwise comparisons did not yield statistically significant $F_{\mathrm{ST}}$ values. The most outstanding populations were those of Poland and northern Belarus, while populations of central Belarus, southern Belarus and Slovakia were genetically indistinguishable. The Polish population was shown to be distinct from all studied populations $(P=0.01$ for comparison with Slovakia, $P<0.005$ for all other comparisons), while in the case of northern Belarus, the only insignificant $F_{\mathrm{ST}}$ value was for a comparison with the southern part of the country.

Our results have demonstrated that the Y-STR haplotype distribution does not reflect the linguistic and/or historical affiliations between Slavic populations. The Polish paternal lineages revealed by Y-chromosomal microsatellite haplotype analysis were previously reported to be distant from a number of non-Slavic European populations and Slavicspeaking Muscovites (Ploski et al. 2002), but no Slavic populations inhabiting Poland's geographic neighbours were taken into consideration. Despite the usage of very closely related languages by Poles and Slovaks as well as over half a millennium of a common state bordering the majority of Poles and Belarusians, the Polish Y-STR haplotype heritage was shown to be distinct from that of both neighbouring Slavic nations. On the other hand, analysis of Y chromosome haplotypes defined by 18 loci has revealed genetic homogeneity between Slovaks and two subpopulations of Belarus, although both populations are geographically distant and isolated, speak tongues belonging to separate branches of the Slavic language group, and have never shared common state borders throughout their histories.

Since for the majority of other Slavic populations, only nine-locus haplotypes (DYS19, DYS389I, DYS389II-I, DYS390, DYS391, DYS392, DYS393, and DYS385 a/b) were available, only these loci were used for further analysis. A comparison of our Polish haplotypes defined by the selected nine loci with data for six Polish regional subpopulations from the $\mathrm{Y}$ chromosome haplotype reference database confirmed previously observed homogeneity of Polish subpopulations $\left(F_{\mathrm{ST}}=-0.0003 ; P=0.66\right.$ ) (Ploski et al. 2002), and in AMOVA, all Polish samples were combined. Results revealed four clusters of Slavic populations connected by a network of statistically insignificant $F_{\mathrm{ST}}$ values $(P>0.05)$ : (1) all Western-Slavic and EasternSlavic populations, Slovenes and western Croats; (2) Lusatians; (3) Southern-Slavic northern Croats and Bosnians; (4) Southern-Slavic Serbs, Macedonians, and Bulgarians (Table 1). However, at the significance level of 0.01 , only one such cluster involving all Slavic populations was disclosed. The distinctiveness of Southern-Slavic populations was observed as a separate branch in a neighbour-joining tree, while multidimensional scaling has displayed a nucleus of seven genetically indistinguishable populations with very small relative genetic distances, which involved population samples of Eastern-Slavic (Ukrainian, Russian, Belarusian), Western-Slavic (Slovak) as well as SouthernSlavic (Slovene) origin (Fig. 1).

Since there is no clear consensus over the accuracy of different statistical parameters estimating genetic distances between populations in studies using microsatellite markers, both a classical allele frequency-based differentiation estimator $\left(F_{\mathrm{ST}}\right)$ and its stepwise mutation model-based analogue $\left(R_{\mathrm{ST}}\right)$ are commonly reported (Balloux and Lugon-Moulin 2002). Therefore, we applied both distance methods to assess genetic relations between various Slavic and non-Slavic populations. In accordance with results obtained for autosomal STRs in various human populations (Pérez-Lezaun et al. 1997; Destro-Bisol et al. 2000) and for Y-chromosomal microsatellites in sub-Saharan Africans (Caglià et al. 2003), the pattern of Y-STR interpopulation diversity among Slavs and neighbouring populations, based on $F_{\mathrm{ST}}$ values, appeared to be congruent with known ethnohistorical relationships, while that based on $R_{\mathrm{ST}}$ values revealed unexpected and unconvincing population affinities.

Both the multidimensional scaling plot and the neighbour-joining tree, based on the $F_{\mathrm{ST}}$ values, revealed genetic proximity between related populations: (1) Germans from Bavaria and Saxony, (2) Italians from Latium and Veneto, (3) Turks from Anatolia and Bulgaria, and (4) Balts from Latvia and Lithuania (Fig. 1). The $F_{\mathrm{ST}}$-based results were consistent with expectations also in case of three isolated Slavic populations: (1) Lusatians from southeastern Germany, who are descendants of Slavic tribes that have inhabited the lands between the Elbe and Oder rivers since the fifth century (Encyclopædia Britannica 2006), (2) Polish Belarusians, who colonised parts of Podlachia (northeastern Poland) in the 15th to 16th centuries after arrival from the Hrodna region (Wiśniewski 1964), and (3) a community of Russian settlers (Old Believers), who arrived in Podlachia in the eighteenth century from the Pskov and Novgorod regions (Grek-Pabisowa 1968). All three ethnic groups were shown to be homogeneous with only one of all compared populations (Table 1), representing their population of origin. Lusatians revealed Y-STR homogeneity with the neighbouring population inhabiting areas from which they are supposed to migrate, i.e. with Poles. In the case of Podlachian Belarusians, such a population of origin was geographically the closest population of central Belarus (involving the city of Hrodna), while in the case of Polish Old Believers it was Russians from the Novgorod region.

On the other hand, in the $R_{\mathrm{ST}^{-}}$-based multidimensional scaling plot and the neighbour-joining tree, only the two 


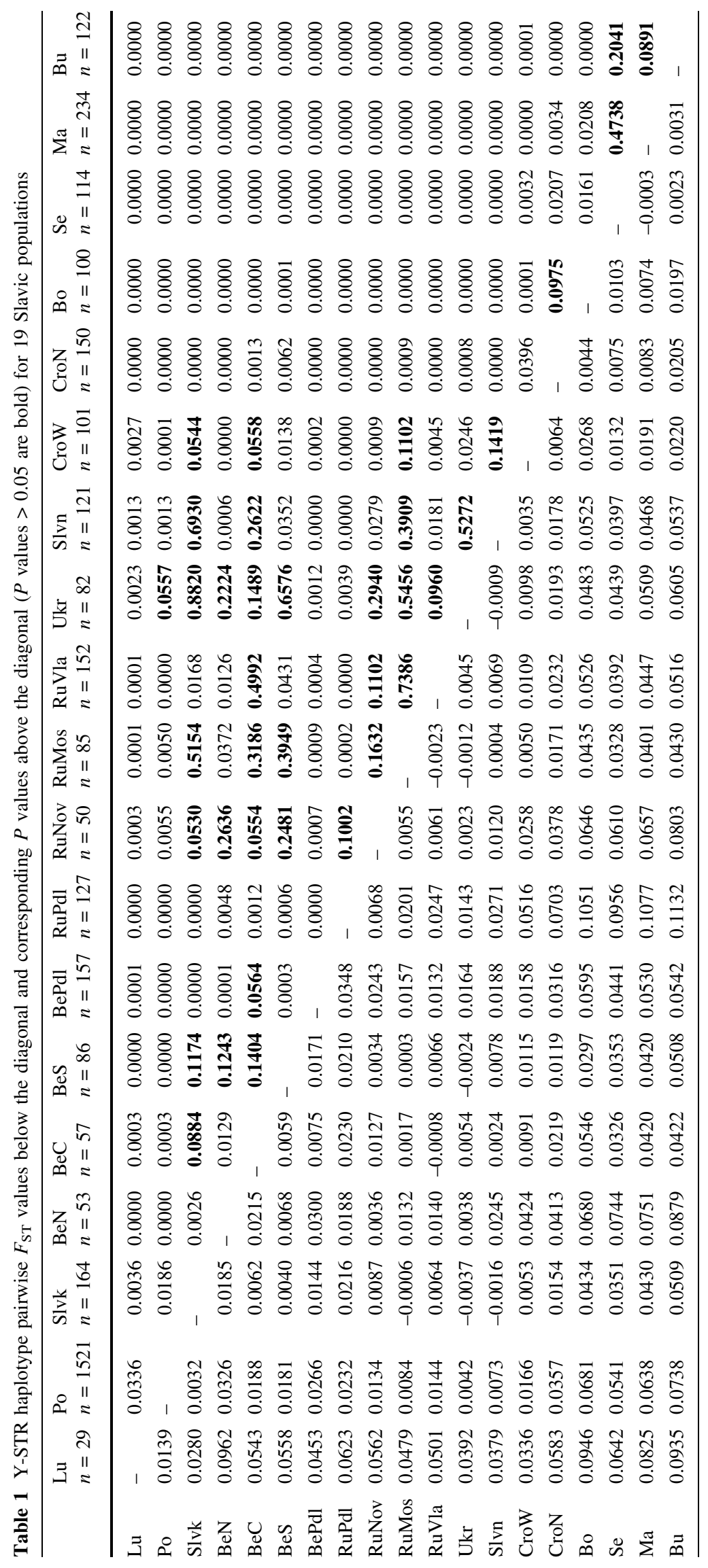


Fig. 1 Two-dimensional plot obtained from multidimensional scaling, and a neighbour-joining tree, based on pairwise $F_{\mathrm{ST}}$ values for nine-locus Y-STR haplotypes observed in 19 Slavic and 9 non-Slavic populations. Ellipses are traced around genetically homogeneous northern Slavic populations and clusters of nonSlavic populations with known ethno-historical affiliations. Arrows indicate historically proved directions of migrations. A dotted line connects populations with a disputed direction of migration, which inhabit areas designated according to the various sources as the Slavic homeland
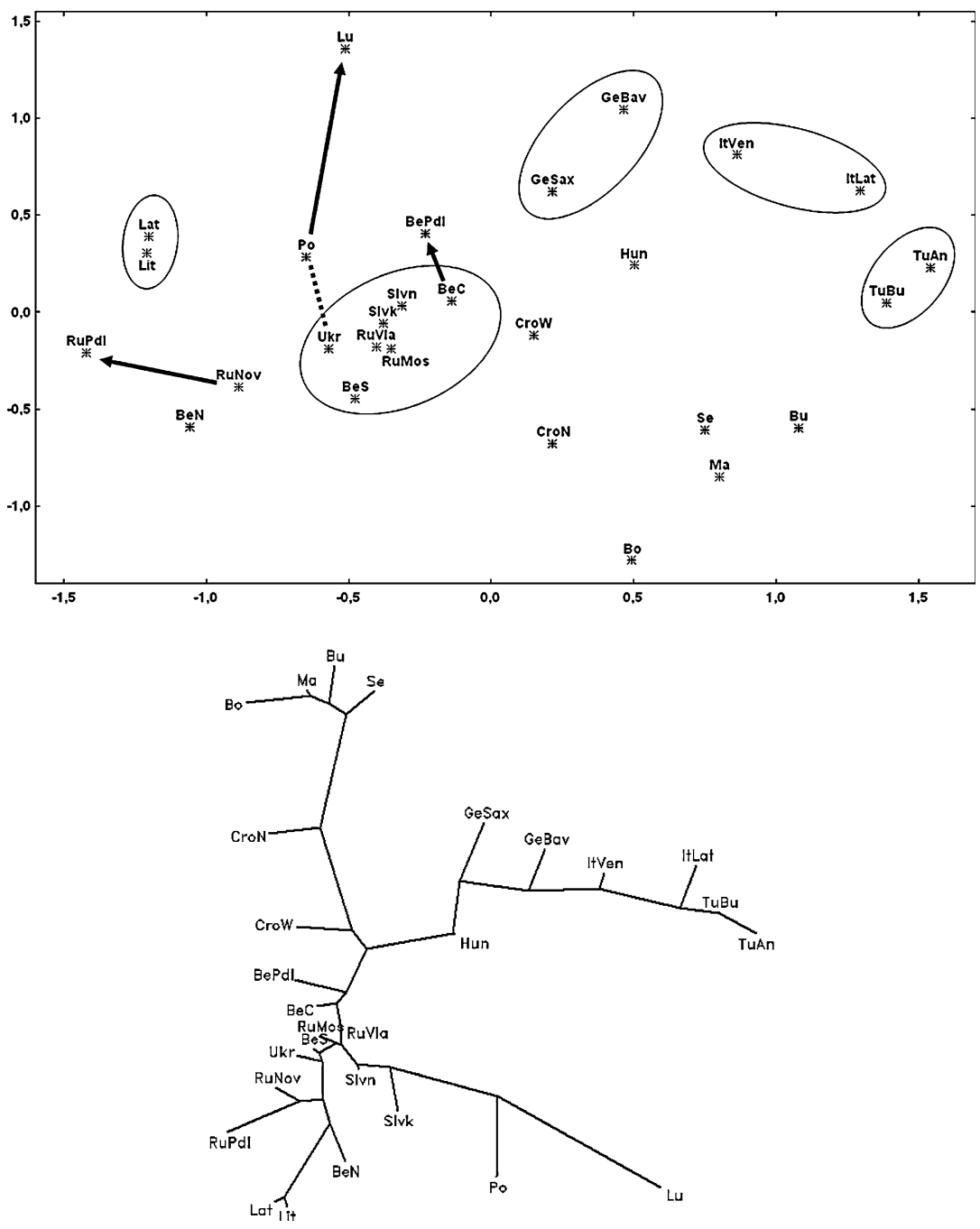

2003). Therefore, in further analysis, we focused only on the results obtained by the classical allele frequency-based approach for estimation of Y-STR genetic distances.

Comprehensive analysis of Slavic Y-chromosomal microsatellite haplotypes on a European scale confirmed previous observations for 18 Y-STR loci in the Polish, Slovak and Belarusian populations: no relationship between the customary linguistic division of Slavs and the YSTR haplotype distribution was disclosed. The most apparent genetic distance was found between the northern (Eastern and Western) and Southern Slavs, who at the end of the 9th century were separated by the invasion of FinnoUgric Hungarians. The AMOVA showed that the variation observed between both population groups was $4.3 \%$ $\left(F_{\mathrm{CT}}=0.0428 ; P=0.0003\right)$, which was higher than the level of genetic variance among populations within the groups $\left(1.2 \% ; F_{\mathrm{SC}}=0.0130 ; P<0.0001\right)$. This difference was even more profound when the $R_{\mathrm{ST}}$-based distance method was applied: genetic variation between both population clusters was $19.8 \%\left(R_{\mathrm{CT}}=0.1984 ; P=0.0002\right)$ 
Fig. 2 Two-dimensional plot obtained from multidimensional scaling, and a neighbour-joining tree, based on pairwise $R_{\mathrm{ST}}$ values for ninelocus Y-STR haplotypes observed in 19 Slavic and nine non-Slavic populations. An ellipse is traced around a cluster of populations with known ethno-historical affiliations

Lu Lusatians; Po Poles; Slvk Slovaks; $B e N, B e C, B e S, B e P d l$ Belarusians from northern Belarus, central Belarus, southern Belarus, Podlachia; RuPdl, RuNov, RuMos, RuVla Russians from Podlachia (Old Believers), Novgorod region, Moscow region, Vladivostok region; Ukr Ukrainians; Slvn Slovenes; CroW, CroN Croats from western Croatia, northern Croatia (Zagreb region); Bo Bosnians; Se Serbs; $M a$ Macedonians; $B u$ Bulgarians; Lit Lithuanians; Lat Latvians; GeBav, GeSax Germans from Bavaria, Saxony (Dresden region); ItLat, ItVen Italians from Latium, Veneto;

Hun Hungarians; TuAn, TuBu

Turks from Anatolia,

Bulgaria

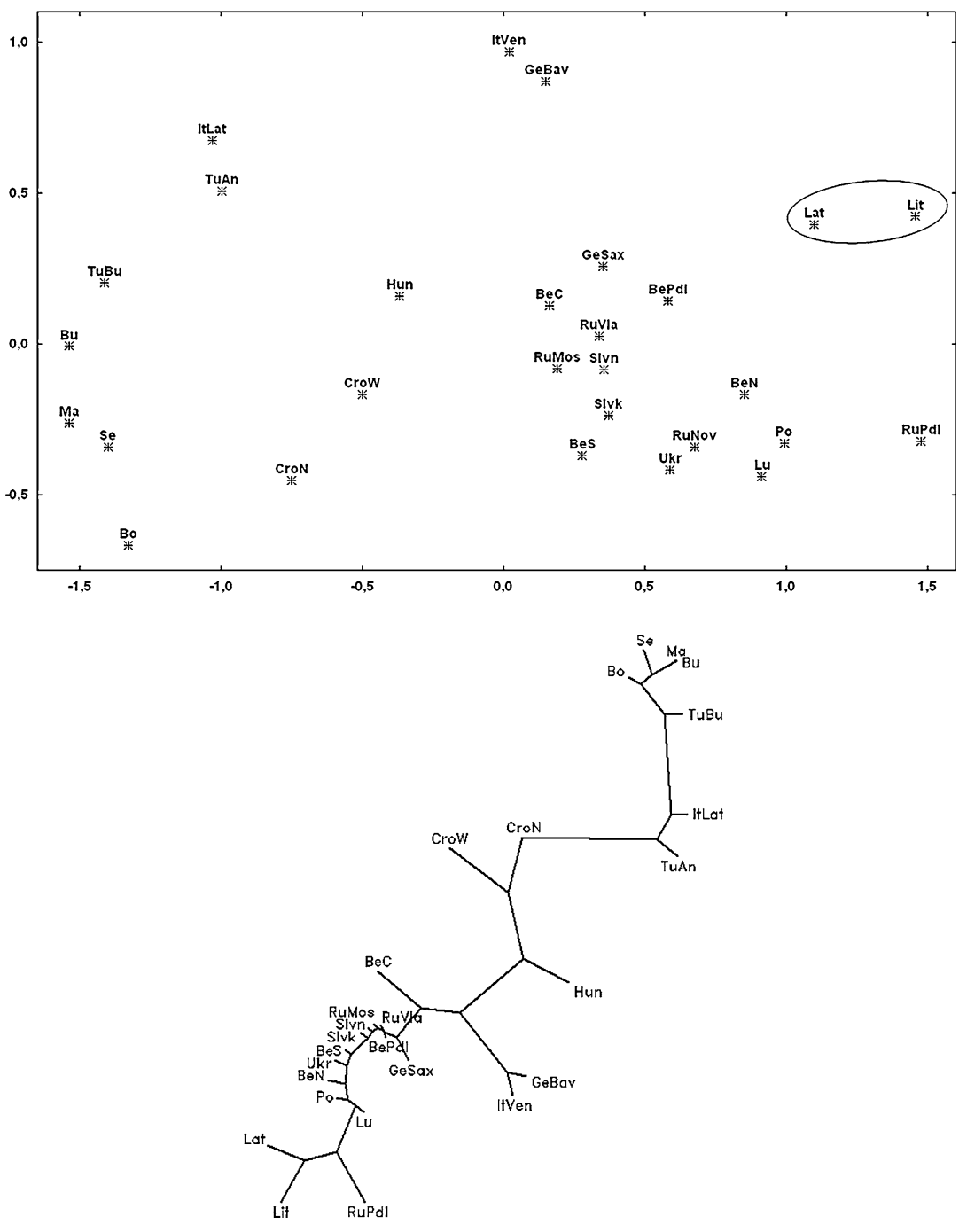

as well. Roewer et al. (2005) attributed a possible explanation for these differences to the admixture of $\mathrm{Y}$ chromosomes of Finno-Ugric and Turkic-speaking peoples who had invaded and settled in the Danube basin and the Balkans. However, we found that the only population that revealed an insignificant $F_{\mathrm{ST}}$ value in comparison with the Finno-Ugric Hungarians was the population of western Croatia, and this putative admixture did not significantly affect the Y-STR proximity of western Croats to Eastern and Western Slavs (Table 1). All other $F_{\text {ST }}$ values obtained for comparison of nine-locus haplotypes of Hungarians and Turks from Bulgaria and Anatolia, with those of 19 Slavic populations appeared to be statistically significant $(P=0.01$ for a comparison of Hungarians with the population of central Belarus, $P=0.002$ for a comparison of Bulgarian Turks with Bulgarians, $P \leq 0.0003$ for all other comparisons). Thus, the contribution of the $\mathrm{Y}$ chromosomes of peoples who settled in the region before the Slavic expansion to the genetic heritage of Southern Slavs genetically distinct from their northern linguistic relatives 
is the most likely explanation for this phenomenon. On the other hand, our results indicate no significant genetic traces of pre-sixth-century inhabitants of present-day Slovenia in the Slovene Y chromosome genetic pool.

Although the existence of the Balto-Slavic linguistic community, or at least territorial contiguity of Proto-Baltic and Proto-Slavic in the past, is generally accepted (Schenker 1995), AMOVA revealed significant differences in Y-STR distribution between Slavic and Baltic populations $(P<0.005$ for all pairwise comparisons), which is likely to result from the previously observed different $\mathrm{Y}$ chromosomal haplogroup distribution (Rosser et al. 2000). The Baltic populations are characterised by the high incidence of the Y-chromosomal haplogroup N3 (47\% among Lithuanians, 32\% among Latvians) (Rosser et al. 2000; Zerjal et al. 2001). Its distribution pattern in Slavic populations indicates that Proto-Slavs did not carry this lineage at a substantial frequency, since it is relatively rare among Slavs and at high frequency was observed only in some Russian subpopulations (Malyarchuk et al. 2004). Since at the significance level equal to 0.01 , the only population that did not yield statistically significant $F_{\mathrm{ST}}$ values for comparisons with other Slavic and both Baltic populations was the Slavic-speaking population of northern Belarus, we estimated haplogroup N3 frequencies in the three Belarusian subpopulations. The results suggest that the uniqueness of the northern Belarusian population is most likely due to the high incidence of $\mathrm{Y}$ chromosomes from the haplogroup N3 (18.9\%), which has half the frequency in central and southern Belarus (8.8 and $8.1 \%$, respectively). Therefore, although the early ethnogenesis of the Belarusian nation has customarily been linked to the gradual Slavicisation of the homogeneous Baltic substrate on the territory of present-day Belarus (Sedov 1970), only northern Belarus seems to be a transient area for the Baltic and Slavic settlement. Apart from Balts, the N3 Y chromosomes are also prevalent among Finno-Ugrians (Rosser et al. 2000; Zerjal et al. 2001), but it was found that Y-STR haplotypes from the haplogroup N3 differ in Baltic and Finno-Ugric populations, most likely due to two distinct migration waves of people carrying N3 Y chromosomes (Zerjal et al. 2001; Kasperavičiūte et al. 2004). On the contrary to the Finno-Ugric populations, where allele DYS19*14 is the most common among haplogroup N3 males, allele DYS19*15 is the most frequent in the Baltic haplogroup N3 (Kasperavičiūte et al. 2004), and was also the most frequent allele in the haplogroup $\mathrm{N} 3$ in northern Belarus $(60.0 \%)$, providing additional evidence for the presence of the Baltic substrate in the genetic pool of Belarusians from the northernmost part of the country.

Localisation of the Slavic homeland prior to their great expansion in the fifth to sixth centuries is one of the key problems of European history in the first millennium AD. Although it is assumed that prehistorically the original habitat of Slavs was Asia, from which they migrated in the third or second millennium BC to populate parts of Eastern Europe (Encyclopædia Britannica 2006), a debate concerning the European homeland of Slavs seems to remain unsolved. Because Slavs unequivocally enter the records of history as late as the sixth century $\mathrm{AD}$, when their expansion in Eastern Europe was already advanced, different theories concerning the Slavs' geographic origin based on archaeological, anthropological and/or linguistic data have been formulated. Two such theories have gained the largest support among the scientists (Schenker 1995), one placing the cradle of Slavs in the watershed of the Vistula and Oder rivers (present-day Poland), and the other locating it in the watershed of the middle Dnieper (present-day Ukraine). Our results indicate that using the population-of-origin approach based on the AMOVA, as many as nine $(P>0.05)$ or ten $(P>0.01)$ populations can be traced back to the lands of present-day Ukraine, including EasternSlavic Russians and Belarusians, Western-Slavic Poles and Slovaks, and Southern-Slavic Slovenes and Croats. On the other hand, the Polish population gave insignificant $F_{\mathrm{ST}}$ values in pairwise comparisons with only one (i.e. Ukrainians) or three (i.e. Ukrainians, Slovaks, and Lusatians) populations $(P>0.05$ or 0.01 , respectively). Moreover, the Y-STR genetic distance between Poles and Belarusians, who are geographic neighbours (Table 1), excludes significant gene flow between the two populations and localisation of Belarusians' ancestors in present-day Poland.

In conclusion, we have demonstrated that Y-STR haplotype distribution divides Slavs into two genetically distant groups: one encompassing all Western Slavs, Eastern Slavs, Slovenes and Western Croats, and the other involving all remaining Southern Slavs. Many northern Slavic populations are genetically indistinguishable in regard to the nine-locus Y-STR haplotype variation, and this homogeneity extends from the Alps to the upper Volga, and even as far as the Pacific Ocean (eastern Russia), regardless of linguistic, cultural and historical affiliations of the Slavic ethnicities. The example of Slovaks and Belarusians shows that this homogeneity is likely to be extended to other Y-chromosomal microsatellites as well. Results of the interpopulation Y-STR haplotype analysis exclude a significant contribution of ancient tribes inhabiting present-day Poland to the gene pool of Eastern and Southern Slavs, and suggest that the Slavic expansion started from present-day Ukraine, thus supporting the hypothesis that places the earliest known homeland of Slavs in the basin of the middle Dnieper. To our knowledge, this is the first report on the use of genetic markers in solving the question of the localisation of the Slavic homeland. 


\section{References}

Balloux F, Lugon-Moulin N (2002) The estimation of population differentiation with microsatellite markers. Mol Ecol 11:155165

Butler JM (2003) Recent developments in Y-short tandem repeat and Y-single nucleotide polymorphism analysis. Forensic Sci Rev 15:91-111

Caglià A, Tofanelli S, Coia V, Boschi I, Pescarmona M, Spedini G, Pascali V, Paoli G, Destro-Bisol G (2003) A study of Ychromosome microsatellite variation in sub-Saharan Africa: a comparison between $\mathrm{F}_{\mathrm{ST}}$ and $\mathrm{R}_{\mathrm{ST}}$ genetic distances. Hum Biol 75:313-330

Das B, Chauhan PS, Seshadri M (2004) Minimal sharing of Ychromosome STR haplotypes among five endogamous population groups from western and southwestern India. Hum Biol 76:743-763

Destro-Bisol G, Spedini G, Pascali VL (2000) Application of different genetic distance methods to microsatellite data. Hum Genet 106:130-132

Encyclopædia Britannica (2006) Slav in Encyclopædia Britannica Online (http://www.search.eb.com/eb/article-9068162)

Excoffier L, Laval G, Schneider S (2005) Arlequin (version 3.0): an integrated software package for population genetics data analysis. Evol Bioinform Online 1:47-50

Felsenstein J (2004) PHYLIP (Phylogeny Inference Package) version 3.6. Department of Genome Sciences, University of Washington, Seattle

Grek-Pabisowa I (1968) Rosyjska gwara starowierców w województwach olsztyńskim i białostockim. Russian dialect of Old-Believers in the administrative regions of Olsztyn and Bialystok. Ossolineum, Wroclaw

Immel U-D, Krawczak M, Udolph J, Richter A, Rodig H, Kleiber M, Klintschar M (2006) Y-chromosomal STR haplotype analysis reveals surname-associated strata in the East-German population. Eur J Hum Genet 14:577-582

Jobling MA, Tyler-Smith C (2003) The human Y chromosome: an evolutionary marker comes of age. Nat Rev Genet 4:598-612

Kasperavičiūte D, Kučinskas V, Stoneking M (2004) Y chromosome and mitochondrial DNA variation in Lithuanians. Ann Hum Genet 68:438-452

Kayser M, Krawczak M, Excoffier L, Dieltjes P, Corach D, Pascali V, Gehrig C, Bernini LF, Jespersen J, Bakker E, Roewer L, de Knijff P (2001) An extensive analysis of Y-chromosomal microsatellite haplotypes in globally dispersed human populations. Am J Hum Genet 68:990-1018

Kayser M, Lao O, Anslinger K, Augustin C, Bargel G, Edelmann J, Elias S, Heinrich M, Henke J, Henke L, Hohoff C, Illing A, Jonkisz A, Kuzniar P, Lebioda A, Lessig R, Lewicki S, Maciejewska A, Monies DM, Pawłowski R, Poetsch M, Schmid D, Schmidt U, Schneider PM, Stradmann-Bellinghausen B, Szibor R, Wegener R, Wozniak M, Zoledziewska M, Roewer L, Dobosz T, Ploski R (2005) Significant genetic differentiation between Poland and Germany follows present-day political borders, as revealed by Y-chromosome analysis. Hum Genet 117:428-443

Lauc LB, Peričić M, Klarić IM, Šijački A, Popović D, Janićijević B, Rudan P (2005) Y chromosome STR polymorphisms in a Serbian population sample. Forensic Sci Int 150:97-101

Lessig R, Edelmann J, Kleemann WJ, Kozhemyako V (2006) Population data of Y-chromosomal STRs in Russian males of the Primorye region population. Forensic Sci Int 159:71-76

Lovrečić L, Ristić S, Brajenović B, Kapović M, Peterlin B (2005) Human Y-specific STR haplotypes in the Western Croatian population sample. Forensic Sci Int 149:257-261
Malyarchuk B, Derenko M, Grzybowski T, Lunkina A, Czarny J, Rychkov S, Morozova I, Denisova G, Miściska-Śliwka D (2004) Differentiation of mitochondrial DNA and Y chromosomes in Russian populations. Hum Biol 76:877-900

Marjanovic D, Bakal N, Pojskic N, Kapur L, Drobnic K, Primorac D, Bajrovic K, Hadziselimovic R (2005) Population data for the twelve Y-chromosome short tandem repeat loci from the sample of multinational population in Bosnia and Herzegovina. J Forensic Sci 50:223-225

Pepinski W, Niemcunowicz-Janica A, Skawronska M, Koc-Zorawska E, Janica J, Soltyszewski I (2004a) Y-chromosome STR haplotypes in a population sample of the Byelorussian minority living in the northeastern Poland. Forensic Sci Int 140:117-121

Pepinski W, Niemcunowicz-Janica A, Skawronska M, Koc-Zorawska E, Janica J, Soltyszewski I (2004b) Y-chromosome STR haplotypes and alleles in the population sample of Old Believers residing in the Northeastern Poland. Forensic Sci Int 143:65-68

Pérez-Lezaun A, Calafell F, Mateu E, Comas D, Ruiz-Pacheco R, Bertranpetit J (1997) Microsatellite variation and the differentiation of modern humans. Hum Genet 99:1-7

Peričić M, Klarić IM, Lauc LB, Janićijević B, Đorđević D, Efremovska L, Rudan P (2005) Population genetics of 8 Y chromosome STR loci in Macedonians and Macedonian Romani (Gypsy). Forensic Sci Int 154:257-261

Ploski R, Wozniak M, Pawlowski R, Monies DM, Branicki W, Kupiec T, Kloosterman A, Dobosz T, Bosch E, Nowak M, Lessig R, Jobling MA, Roewer L, Kayser M (2002) Homogeneity and distinctiveness of Polish paternal lineages revealed by $\mathrm{Y}$ chromosome microsatellite haplotype analysis. Hum Genet 110:592-600

Rębała K, Szczerkowska Z (2005) Polish population study on Y chromosome haplotypes defined by 18 STR loci. Int J Legal Med 119:303-305

Rodig H, Grum M, Grimmecke H-D (2007) Population study and evaluation of $20 \mathrm{Y}$-chromosome STR loci in Germans. Int J Legal Med 121:24-27

Roewer L, Kayser M, Dieltjes P, Nagy M, Bakker E, Krawczak M, de Knijff P (1996) Analysis of molecular variance (AMOVA) of Ychromosome-specific microsatellites in two closely related human populations. Hum Mol Genet 5:1029-1033

Roewer L, Krawczak M, Willuweit S, Nagy M, Alves C, Amorim A, Anslinger K, Augustin C, Betz A, Bosch E, Cagliá A, Carracedo A, Corach D, Dekairelle A-F, Dobosz T, Dupuy BM, Füredi S, Gehrig C, Gusmaõ L, Henke J, Henke L, Hidding M, Hohoff C, Hoste B, Jobling MA, Kärgel HJ, de Knijff P, Lessig R, Liebeherr E, Lorente M, Martínez-Jarreta B, Nievas P, Nowak M, Parson W, Pascali VL, Penacino G, Ploski R, Rolf B, Sala A, Schmidt U, Schmitt C, Schneider PM, Szibor R, Teifel-Greding J, Kayser M (2001) Online reference database of European Ychromosomal short tandem repeat (STR) haplotypes. Forensic Sci Int 118:106-113

Roewer L, Croucher PJP, Willuweit S, Lu TT, Kayser M, Lessig R, de Knijff P, Jobling MA, Tyler-Smith C, Krawczak M (2005) Signature of recent historical events in the European $\mathrm{Y}$ chromosomal STR haplotype distribution. Hum Genet 116:279-291

Rolf B, Meyer E, Brinkmann B, de Knijff P (1998) Polymorphism at the tetranucleotide repeat locus DYS389 in 10 populations reveals strong geographic clustering. Eur J Hum Genet 6:583588

Rootsi S, Magri C, Kivisild T, Benuzzi G, Help H, Bermisheva M, Kutuev I, Barać L, Peričić M, Balanovsky O, Pshenichnov A, Dion D, Grobei M, Zhivotovsky LA, Battaglia V, Achilli A, AlZahery N, Parik J, King R, Cinnioğlu C, Khusnutdinova E, Rudan R, Balanovska E, Scheffrahn W, Simonescu M, Brehm A, Goncalves R, Rosa A, Moisan J-P, Chaventre A, Ferak V, Füredi 
S, Oefner PJ, Shen P, Beckman L, Mikerezi I, Terzić R, Primorac D, Cambon-Thomsen A, Krumina A, Torroni A, Underhill PA, Santachiara-Benerecetti AS, Villems R, Semino O (2004) Phylogeography of Y-chromosome haplogroup I reveals distinct domains of prehistoric gene flow in Europe. Am J Hum Genet 75:128-137

Rosser ZH, Zerjal T, Hurles ME, Adojaan M, Alavantic D, Amorim A, Amos W, Armenteros M, Arroyo E, Barbujani G, Beckman G, Beckman L, Bertranpetit J, Bosch E, Bradley DG, Brede G, Cooper G, Corte-Real HB, de Knijff P, Decorte R, Dubrova YE, Evgrafov O, Gilissen A, Glisic S, Golge M, Hill EW, Jeziorowska A, Kalaydjieva L, Kayser M, Kivisild T, Kravchenko SA, Krumina A, Kucinskas V, Lavinha J, Livshits LA, Malaspina P, Maria S, McElreavey K, Meitinger TA, Mikelsaar AV, Mitchell RJ, Nafa K, Nicholson J, Norby S, Pandya A, Parik J, Patsalis PC, Pereira L, Peterlin B, Pielberg G, Prata MJ, Previdere C, Roewer L, Rootsi S, Rubinsztein DC, Saillard J, Santos FR, Stefanescu G, Sykes BC, Tolun A, Villems R, TylerSmith C, Jobling MA (2000) Y-chromosomal diversity in Europe is clinal and influenced primarily by geography rather then by language. Am J Hum Genet 67:1526-1543

Rybakowski JK, Borkowska A, Czerski PM, Hauser J (2002) Eye movement disturbances in schizophrenia and a polymorphism of catechol- $O$-methyltransferase gene. Psychiatry Res 113:49-57

Schenker AM (1995) The dawn of Slavic: an introduction to Slavic philology. Yale University Press, New Haven

Sedov VV (1970) Slavâne Verhnego Podneprov'â i Podvin'â. The Slavs of the basin of the upper Dnieper and Western Dvina. Nauka, Moscow
Semino O, Passarino G, Oefner PJ, Lin AA, Arbuzova S, Beckman LE, De Benedictis G, Francalacci P, Kouvatsi A, Limborska S, Marcikiæ M, Mika A, Mika B, Primorac D, SantachiaraBenerecetti AS, Cavalli-Sforza LL, Underhill PA (2000) The genetic legacy of Paleolithic Homo sapiens sapiens in extant Europeans: a Y chromosome perspective. Science 290:11551159

Slatkin M (1995) A measure of population subdivision based on microsatellite allele frequencies. Genetics 139:457-462

Spiroski M, Arsov T, Krüger C, Willuweit S, Roewer L (2005) Ychromosomal STR haplotypes in Macedonian population samples. Forensic Sci Int 148:69-73

Weale ME, Yepiskoposyan L, Jager RF, Hovhannisyan N, Khudoyan A, Burbage-Hall O, Bradman N, Thomas MG (2001) Armenian $\mathrm{Y}$ chromosome haplotypes reveal strong regional structure within a single ethno-national group. Hum Genet 109:659-674

Weale ME, Weiss DA, Jager RF, Bradman N, Thomas MG (2002) Y chromosome evidence for Anglo-Saxon mass migration. Mol Biol Evol 19:1008-1021

Wiśniewski J (1964) Rozwój osadnictwa na pograniczu polsko-ruskolitewskim od końca XIV do połowy XVII wieku. Development of the settlement in the Polish-Ruthenian-Lithuanian borderland from the end of the 14th century to the middle of the 17th century. Acta Balt Slav 1:115-136

Zerjal T, Beckman L, Beckman G, Mikelsaar A-V, Krumina A, Kučinskas V, Hurles ME, Tyler-Smith C (2001) Geographical, linguistic and cultural influences on genetic diversity: $\mathrm{Y}$ chromosomal distribution in Northern European populations. Mol Biol Evol 18:1077-1087 